\title{
Anti-HIV and Anti-Candidal Effects of Methanolic Extract from Heteropterys brachiata
}

\author{
Maira Huerta-Reyes ${ }^{1}$, Luis O. Sánchez-Vargas ${ }^{2}$, Getsemaní S. Villanueva-Amador ${ }^{3}$ \\ and Luis A. Gaitán-Cepeda ${ }^{3, * \text { (D) }}$
}

1 Unidad de Investigación Médica en Enfermedades Nefrológicas, Hospital de Especialidades “Dr. Bernardo Sepúlveda Gutiérrez", Centro Médico Nacional Siglo XXI, Instituto Mexicano del Seguro Social, Ciudad de México 06720, Mexico; chilanguisima@yahoo.com

2 Laboratorio de Bioquímica y Microbiología Oral, Facultad de Estomatología, Universidad Autónoma de San Luis Potosí, San Luis Potosí 78290, Mexico; lo.sanchezvargas@gmail.com

3 Departamento de Medicina y Patología Oral y Maxilofacial, División de Estudios de Postgrado e Investigación, Facultad de Odontología, Universidad Nacional Autónoma de México, Circuito Institutos s/n, Ciudad Universitaria, Coyoacán, Ciudad de México 04510, Mexico; purpureakush@ciencias.unam.mx

* Correspondence: lgaitan@unam.mx; Tel.: +52-(55)-56225560

Citation: Huerta-Reyes, M.;

Sánchez-Vargas, L.O.;

Villanueva-Amador, G.S.

Gaitán-Cepeda, L.A. Anti-HIV and

Anti-Candidal Effects of Methanolic

Extract from Heteropterys brachiata. Int

J. Environ. Res. Public Health 2021, 18,

7270. https://doi.org/10.3390/

ijerph18147270

Academic Editors:

Elizabeth Armstrong-Mensah and

Paul B. Tchounwou

Received: 5 April 2021

Accepted: 3 July 2021

Published: 7 July 2021

Publisher's Note: MDPI stays neutra with regard to jurisdictional claims in published maps and institutional affiliations.

Copyright: (c) 2021 by the authors. Licensee MDPI, Basel, Switzerland. This article is an open access article distributed under the terms and conditions of the Creative Commons Attribution (CC BY) license (https:/ / creativecommons.org/licenses/by/ $4.0 /)$.
Abstract: Nowadays, the HIV pandemic is far from controlled. HIV+/AIDS patients show a serious risk of developing resistance to HIV antiretroviral drugs and to be orally colonized by albicans and non-albicans Candida strains resistant to antifungals. As a consequence, new drugs that possess anti-candidal and anti-HIV effects would represent an alternative in the comprehensive treatment of HIV+/AIDS patients. The present study evaluates the possible anti-HIV and anti-Candida effects of a methanolic extract from Heteropterys brachiata $(\mathrm{Hb} \mathrm{MeOH})$, an American tropical plant. The anti-HIV effect of $\mathrm{Hb} \mathrm{MeOH}$ was tested using a non-radioactive colorimetric method (Lenti $\mathrm{RT}^{\circledR}$ Activity Assay; Cavidi Tech) that uses reverse transcriptase of HIV-1 enzyme as enzymatic target. The anticandidal effect of $\mathrm{HbMeOH}$ extract was evaluated by following a standardized test protocol of microdilution for yeast using the Candida albicans strain $\mathrm{ATCC}^{\circledR} 90028$. The $\mathrm{Hb} \mathrm{MeOH}$ at $1 \mathrm{mg} / \mathrm{mL}$ concentration shows 38.5\% RT-HIV inhibition, while $\mathrm{Hb} \mathrm{MeOH}$ at $10 \mathrm{mg} / \mathrm{mL}$ concentration produced $98 \%$ C. albicans growth inhibition. Our findings show that the $\mathrm{Hb} \mathrm{MeOH}$ possesses a strong anticandidal activity and moderate anti-HIV effect and suggests that the plant extract could be considered as a potential candidate for HIV/AIDS treatment.

Keywords: HIV; AIDS; candidiasis; antiretroviral treatment; antifungal treatment; Heteropterys; Malpighiaceae

\section{Introduction}

In 2021, the pandemic caused by the human immunodeficiency virus (HIV) has been around for 40 years [1]. In this frame time, a great amount of information has been accumulated on HIV and the acquired immune deficiency syndrome (AIDS). Consequently, the knowledge about the etiopathogenesis and natural history of the infection, as well as its prevention and the number of available treatments, has increased. In spite of these efforts, the HIV pandemic is far from controlled and its eradication is not expected in the short-term. Currently, there are about 38 million HIV-positive people worldwide [2]. Despite advances in antiretroviral treatment (ART), and the emergence of new antiretroviral drugs, HIV presents several challenges that must be overcome. One of the most important is the duration one must be on ART, since, regardless of HIV type and the number of drugs administered, one must take ART for a lifetime, which increases the possibility of an infected person developing resistance to ART [3]. Another crucial aspect is that ART drugs are not equally available to all HIV + patients. It is estimated that only $68 \%$ of all patients with $\mathrm{HIV} / \mathrm{AIDS}$ have access to therapy or are on ART [2]. 
Oral candidiasis (OC) is the most frequent oral opportunistic infection in HIV+/AIDS people $[4,5]$. Approximately $80 \%$ of all HIV+/AIDS patients will present with at least one clinical event of OC in their lives and due to their immunodeficiency condition, they will present with continuous reinfections or reactivation of resident strains. Thus, these patients will need to undergo recurrent antimycotic treatments, which will increase the presence of albicans and non-albicans Candida strains resistant to antifungals in their bodies and will also increase the colonization of species with intrinsic resistance such as C. glabrata, C. dubliniensis, and C. auris [6-8].

The aforementioned issues speak to the importance of the development of effective anti-HIV and antifungal drugs with minimal side effects to prevent the spread of antimicrobial resistance. There have been attempts to identify drugs from plants with dual effects as a possible alternative. Different species of Heteropterys have shown pharmacological activity. For example, it has been reported that $H$. tomentosa possesses a double anti-viral effect against poliovirus type 1 and bovine herpes type 1 [9]. Phytometabolites, such as tannins [10,11], flavonoids [12], terpenes [13], polyphenols [14], and saponins [15], obtained from the family Malpighiaceae have been reported to have in vitro anti-candidal activities. The Malpighiaceae family is composed of approximately 75 genera and 1300 species distributed in the American continent. Mexico is considered the center of origin and diversification of this plant family [16]. In the genus Heteropterys, which belongs to the Malpighiaceae family, the presence of tannins and flavonoids have been previously identified in the methanolic extracts for treatment of mental diseases by our research group [17].

The main objective of this study is to discuss the anti-HIV and anti-Candida effects of a methanolic extract from $\mathrm{H}$. brachiata. These new compounds have been found to offer alternative and possibly beneficial, cost-effective forms of antiretroviral therapy.

\section{Materials and Methods}

\subsection{Obtaining the Methanolic Extract of Heteropterys brachiata}

The H. brachiata extract was collected from Quilamula, Huatla, Morelos in Mexico on 4 October 2018. A backup of the extract was collected and sent to the National Herbarium of Mexico's Institute of Biology, UNAM (MEXU). The extract was obtained through the utilization of standardized methods [18]. First, the aerial parts of the plant were dried at room temperature in a dark room for 15 days. Once the plant material was dry, it was ground with a mechanical mill (the weight of the dried and ground plant material was $2.200 \mathrm{~kg}$ ) and dewaxed with $n$-hexane for $24 \mathrm{~h}$. Subsequently, the extraction was carried out $(3 \times)$ overnight by mixing it with $100 \%$ methanol. A volume of $7.5 \mathrm{~L}$ of liquid with methanol was extracted per kilogram of plant material. The plant material was filtered and the liquid part was dried at a high vacuum level with a rotavapor (Rotavapor ${ }^{\circledR}$ BUCHI $\mathrm{R}-100)$, leading to the production of methanolic extract from Heteropterys brachiata $(\mathrm{Hb}$ $\mathrm{MeOH})$. The chemical composition of $\mathrm{Hb} \mathrm{MeOH}$ was characterized and reported by our research group in a previous manuscript [17] and in the patent [18]. The main constituents of the $\mathrm{Hb} \mathrm{MeOH}$ are chlorogenic acid $(3.2 \mathrm{mg} / \mathrm{kg}$ ) and chlorogenic acid methyl ester $(60 \mathrm{mg} / \mathrm{kg})$.

\subsection{Evaluation of the Anti-HIV Effect of Methanolic Extract from Heteropterys brachiata}

The anti-HIV effect of $\mathrm{Hb} \mathrm{MeOH}$ extract was assessed using a non-radioactive colorimetric Lenti RT ${ }^{\circledR}$ Activity Assay (Cavidi Tech, Uppsala, Sweden) that uses HIV-1 reverse transcriptase (RT) enzyme as the enzymatic target. We followed the instructions of the manufacturer. $\mathrm{Hb} \mathrm{MeOH}$ extract of different concentrations was added to each well of the 96-well microtiter plate along with a reaction mixture, containing primer, a nucleotide (5-bromo-3-deoxyribouridine 5'-triphosphate), and buffers. Later, the RT enzyme was added. If there was no inhibition of enzymatic activity, the RT synthesized the DNA. Later, the anti bromo-deoxyribouridine ( $\alpha$-BrdU) antibody conjugated to alkaline phosphatase was placed in all the wells of the microtiter plate. The result was reported as percentage of RT inhibition. The $\mathrm{Hb} \mathrm{MeOH}$ extract was probed at concentrations of 
$1 \mathrm{mg} / \mathrm{mL}, 0.1 \mathrm{mg} / \mathrm{mL}$, and $0.01 \mathrm{mg} / \mathrm{mL}$ in an anti RT VIH kit. To obtain these concentrations, $\mathrm{Hb} \mathrm{MeOH}$ extract was dissolved in DMSO. The experiments were performed in triplicate. Nevirapine $\left(\right.$ Viramune ${ }^{\circledR}$ ), a transcriptase reverse inhibitor, was used as a positive control.

\subsection{Evaluation of the Anti-Candidal Effect of Methanolic Extract from Heteropterys brachiata}

To establish the anti-candidal effect of $\mathrm{Hb} \mathrm{MeOH}$, a standardized test protocol [19] using the Candida albicans strain ATCC $^{\circledR} 90,028$ was performed. The stock solution from the $\mathrm{Hb} \mathrm{MeOH}$ extract was $1 \mathrm{~g} / \mathrm{mL}$ after using DMSO as a dissolvent. Later, from the stock solution, dilutions were made to obtain concentrations 100 times higher than the final concentrate. A second dilution $(1 / 50)$ was then performed by taking $100 \mu \mathrm{L}$ of each concentration and adding it to $4.9 \mathrm{~mL}$ of Roswell Park Memorial Institute (RPMI) 1640 $\left(\right.$ Gibco $\left.^{\circledR}\right)$ medium.

The C. albicans inoculum was prepared in the following way; $C$ albicans strain was incubated at $25^{\circ} \mathrm{C}$ for $24 \mathrm{~h}$ on Sabouraud dextrose/chloramphenicol agar plates (CRITERION TM, HardyDiagnostics, Santa Maria, CA, USA). Later, Five colonies $\geq 1 \mathrm{~mm}$ were taken and incubated with yeast peptone dextrose broth at $37^{\circ} \mathrm{C}$ for $48 \mathrm{~h}$. After incubation, a cell pellet was obtained by centrifugation $(34 \mathrm{~g} / 10 \mathrm{~min}$ ). The nutrient broth was removed and then $5 \mathrm{~mL}$ of $0.01 \mathrm{M}$ phosphate-buffered salt (PBS) was added. The presence of fungal cells was verified by observation under an optical microscope (Leica DM500, objective $40 \times$ ). An aliquot of $30 \mu \mathrm{L}$ was taken by adjusting the inoculum to an optical density of $1-5 \times 10^{3}$ $\mathrm{CFU} / \mathrm{mL}$ and placed in a tube with $700 \mu \mathrm{L}$ of PBS $(2.7 \mathrm{mM}$ potassium chloride and $137 \mathrm{mM}$ sodium chloride, pH 7.4; Sigma-Aldrich, St. Louis, MO-IL, USA) to obtain a total volume of $1 \mathrm{~mL}$. Then, $630 \mu \mathrm{L}$ of inoculum was added to $62,370 \mathrm{~mL}$ of RPMI. The inoculum was stored until it was ready to be used. The microtiter plates were filled with $100 \mu \mathrm{L}$ of inoculum and $100 \mu \mathrm{L}$ of the solution to be tested. The final concentrations of the extract were: $10 \mathrm{mg} / \mathrm{mL}$, $5 \mathrm{mg} / \mathrm{mL}, 2.5 \mathrm{mg} / \mathrm{mL}, 1.25 \mathrm{mg} / \mathrm{mL}, 625 \mu \mathrm{g} / \mathrm{mL}, 312 \mu \mathrm{g} / \mathrm{mL}, 157 \mu \mathrm{g} / \mathrm{mL}, 78 \mu \mathrm{g} / \mathrm{mL}$, $39 \mu \mathrm{g} / \mathrm{mL}$, and $19 \mu \mathrm{g} / \mathrm{mL}$. Columns of the microtiter plates (numbers 1 and 12) served as negative and positive controls, respectively. Number 1 contained $200 \mu \mathrm{L}$ of RPMI medium and number 12 contained $100 \mu \mathrm{L}$ of RPMI with $100 \mu \mathrm{L}$ of inoculum. Plates were incubated at $37^{\circ} \mathrm{C}$ for $24 \mathrm{~h}$. Fluconazole (Flucoxan ${ }^{\circledR}$ ) was used as the reference antifungal to validate the standardization of the M27-A3 method, and for the interpretation of cut-off points. Furthermore, a comparison of the sensitivity or resistance of the C. albicans inoculum was made between the $\mathrm{Hb} \mathrm{MeOH}$ and chlorogenic acid (Sigma-Aldrich, CAS 327-97-9) using standard dilutions.

In both cases, reading of the plates was performed in a microtiter plate reader with a length of $405 \mathrm{~nm}$ using the SKANTI software 3.1, the research editor for Multiskan FC (Thermo Scientific, Waltham, MA, USA). Inhibition is reported as the percentage of inhibition. The research protocol was authorized by an ethical committee of participant institutions.

\section{Results}

\subsection{Anti-HIV Effect of $\mathrm{Hb} \mathrm{MeOH}$ Extract}

The methanolic extract from $H$. brachiata at a concentration of $10 \mathrm{mg} / \mathrm{mL}$ showed a $38.5 \%$ inhibition, while a concentration of $1 \mathrm{mg} / \mathrm{mL}$ showed a $25.8 \%$ inhibition. At a concentration $100 \mu \mathrm{g} / \mathrm{mL}$, the percentage inhibition was $12.5 \%$.

\subsection{Anti-Candidal Effect of $\mathrm{Hb} \mathrm{MeOH}$ Extract}

Following the Clinical \& Laboratory Standards Institute (CLSI) guidelines that state that a strain is considered sensitive to a substance tested if the percentage if inhibition is greater than $50 \%$, the $C$. albicans strains tested showed sensitivity to the methanolic extract from $H$. brachiata.

At a concentration of $10 \mathrm{mg} / \mathrm{mL}$, the $\mathrm{Hb} \mathrm{MeOH}$ extract produced $98 \%$ inhibition, the highest percentage of inhibition obtained. At a concentration of $5 \mathrm{mg} / \mathrm{mL}$, we observed 
an inhibition of $62 \%$. The lowest concentration at which inhibition was obtained (61\%) was $2.5 \mathrm{mg} / \mathrm{mL}$. Table 1 shows the inhibition percentages obtained at different concentrations of $\mathrm{Hb} \mathrm{MeOH}$ and chlorogenic acid. The highest inhibition percentage obtained using chlorogenic acid was $15 \%$.

Table 1. Inhibition of Candida albicans observed at different concentrations of methanolic extract from Heteropterys brachiata and chlorogenic acid.

\begin{tabular}{ccccccccccc}
\hline & \multicolumn{4}{c}{$\begin{array}{c}\mathrm{Hb} \text { MeOH } \\
(\mathbf{m g} / \mathrm{mL})\end{array}$} & \multicolumn{4}{c}{$\begin{array}{c}\text { CHLOROGENIC ACID } \\
(\boldsymbol{\mu g} / \mathrm{mL})\end{array}$} \\
\cline { 2 - 12 } & $\mathbf{1 0}$ & $\mathbf{5}$ & $\mathbf{2 . 5}$ & $\mathbf{1 . 2 5}$ & $\mathbf{0 . 6 2 5}$ & $\mathbf{1 7 . 5}$ & $\mathbf{8 . 7 5}$ & $\mathbf{4 . 3 7}$ & $\mathbf{2 . 1 8}$ & $\mathbf{1 . 0 9}$ \\
\hline Percentage of inhibition & $98 \%$ & $62 \%$ & $61 \%$ & $15 \%$ & $22 \%$ & $15 \%$ & $0 \%$ & $12 \%$ & $4 \%$ & $0 \%$ \\
\hline
\end{tabular}

$\overline{\mathrm{H} b \mathrm{MeOH}}=$ methanolic extract of $\mathrm{H}$. brachiata .

\section{Discussion}

The study evaluated the anti-candidal and anti-HIV-1 effects of a methanolic extract from Heteropterys brachiata as a possible alternative treatment for HIV+/AIDS patients. The medicinal plant extracts are safe, cheap, and effective [20]. Our findings showed that the methanolic extract from $H$. brachiata has moderate anti-HIV inhibitory properties. To the best of our knowledge, this is the first time that this extract has been reported as a potential treatment for HIV. We observed a percentage inhibition of RT HIV-1 considered moderateacting, similar to that reported in other plant extracts [21]. Phytochemical metabolites, such as alkaloids, flavonoids, phenolic compounds, glycosides, tannins, and saponins, protect against the main enzymatic mechanisms of HIV, for a review see [22,23], and particularly, alkaloids [24], saponins [25], and tannins [26] have already been identified as inhibitors of HIV-1 TR. Due the RT HIV-1 moderate-acting inhibition reported in our work, future anti-HIV investigations may consider escalating the metabolites detected in the $\mathrm{HbMeOH}$ extract to see if they can obtain a higher percentage of inhibition, and a variety of $\mathrm{HIV}$ targets for $\mathrm{HbMeOH}$ testing.

Chlorogenic acid was identified as one of the main components in the $\mathrm{Hb} \mathrm{MeOH}$ extract in a previous report from our research group [17]. Compounds derived from chlorogenic acid have been reported to be potent inhibitors of HIV integrase by a number of studies $[27,28]$. In the case of the enzyme HIV-TR, recent research showed that eight chlorogenic acid derivatives exhibited HIV-1 TR inhibition [29]. These data allow us to suggest that compounds derived from chlorogenic acid may represent a source of moderate HIV-1 RT inhibitors. Other authors have focused on the structural modification of chlorogenic acid in order to potentiate its anti-HIV properties through the inhibition of the $\alpha$-glucosidase. Besides the role of the inhibitors of $\alpha$-glucosidase in the progression of diabetes by decreasing carbohydrate digestion and absorption, in recent years, the inhibition of $\alpha$-glucosidase has been considered a promising strategy for the development of novel anti-HIV agents due to the glycosylation of viral envelope glycoproteins [30]. The envelope glycoproteins gp120 and gp41 play crucial roles in HIV entry, thus serving as key targets for the development of HIV entry inhibitors [31]. Inhibitors of $\alpha$-glucosidases can cause glycoproteins to misfolded and remain within the endoplasmic reticulum, interfering with the viral life cycle and infectious process [32]. Thus, Hattori et al. [30] proposed the utilization of novel $\alpha$-glucosidase inhibitors through the optimization of the hydrophilicity of chlorogenic acid by addition of alkyl chains of various lengths. The addition of ketal or acetal bonds to chlorogenic acid derivatives caused an increase in the inhibitory activity of $1 \alpha$-glucosidases. Chlorogenic acid and its derivatives, constitute novel anti-HIV agents.

In HIV+/AIDS patients, including those on antiretroviral therapy, the most common oral opportunistic infection is Oropharyngeal candidiasis [4,5]. The presence of OC is an important prognostic value in HIV / AIDS patients [33], therefore medical control of oral candidiasis is essential. However, there are several obstacles that have prevented the achievement of this goal. On one hand, there is a limited amount of suitable, effective, and universally affordable care for people living with HIV / AIDS in de- 
veloping countries [34]. On other hand, there is an increase in the prevalence of drugresistant Candida, and the emergence of other inherently drug-resistant Candida species [7]. Therefore, the development of an alternative, efficient antifungal drug is necessary and essential [35]. Several plants possess effective anti-candidal properties. Cinnamomum zeylanicum, eucalyptus, lemongrass oil, ginger grass oil, peppermint, coriander, and Thymus villosus all possess anticandidal properties [36]. Our findings showed that the $\mathrm{Hb} \mathrm{MeOH}$ at a concentration of $2.5 \mathrm{mg} / \mathrm{mL}$, reaching a maximum inhibition (98\%) at a concentration of $10 \mathrm{mg} / \mathrm{mL}$ possesses properties against C. albicans (61\% inhibition). Interestingly, the compound chlorogenic acid, which has been described before as one of the main compounds in $\mathrm{Hb} \mathrm{MeOH}$ [17], showed a 15\% inhibition when isolated, representing $\leq 25 \%$ of inhibition when compared with the crude extract. Consequently, our results reveal that the crude plant extract is a powerful medicine [37]. In addition, anti-candidal metabolites derived from the Malpighiaceae family such as tannins [10,11], flavonoids [32], terpenes [13], polyphenols [14], and saponins [15], have been reported. The phytochemical screening of Heteropterys brachiata extract exhibited the presence of alkaloids, saponins, and tannins. Nevertheless, the identification of the possible and specific metabolites related to the antiviral and anticandidal effects is beyond the objective of this study, thus further research to elucidate this effect is necessary.

For HIV+ / AIDS patients, the existence of a potential alternative drug with dual therapeutic effect is of utmost importance. Our results support this possible alternative since the methanolic extract from $H$. brachiata showed strong anti-candidal activity and moderate anti-HIV activity. There are two precedents in this regard; both emerged since the introduction of protease inhibitors of HIV-1 (PI-HIV-1) to antiretroviral therapy and the consequent establishment of combined antiretroviral therapy (cART) [38]. cART decreases the viral load of HIV-1 and has a direct effect on the treatment and control of other opportunistic infectious diseases [39].

A decrease in oral candidiasis has been reported, as well as a regression of Kaposi's sarcoma related to HIV (KS-HIV). In the case of OC, cART produced a dramatic decrease, especially in the pseudomembranous clinical form. The decrease in OC prevalence was attributed to improvements in immune response (increase of CD4+ lymphocytes cell count). It was reported that strains of Candida spp. isolated from HIV+ people, were susceptible to saquinavir (a protease inhibitor) and indinavir, with $97 \%$ and $52 \%$ susceptibility, respectively [40]. Regarding Kaposi sarcoma, it has been reported that PI-based ART or NNRTIbased ART significantly decreased incidence rates by at least 10-fold among HIV+/AIDS people who received no ARVs compared to those receiving ART [41]. Even though the effects of cART on HHV-8 have not been fully elucidated, PI appears to possess a direct antiangiogenic property [42].

The possibility of the existence of a potential alternative anti-HIV drug with an anticandidal effect was discussed in this paper. Although these are empirical results that need to be confirmed experimentally, they show the possibility that an extract from plants with a double therapeutic effect can be used to treat both HIV and OC. For a disease like HIV / AIDS where there is an enormous demand for ART drugs, advances in phytopharmacy could help close the gap. Technological development and the standardization of procedures for the production and purification of natural extracts, will make this possible.

\section{Conclusions}

Our findings show that methanolic extract from $\mathrm{H}$. brachiata is a potential alternative to ART for HIV treatment and treatment for OC. Given the low cost of production, it is cost effective and affordable. The crude extract possesses a four-times-higher inhibition of C. albicans than pure compound chlorogenic acid. 
Author Contributions: Conceptualization, M.H.-R. and L.A.G.-C.; Formal analysis, M.H.-R., L.O.S.V., G.S.V.-A., and L.A.G.-C.; Investigation, G.S.V.-A. and L.A.G.-C.; Methodology, M.H.-R. and L.O.S.-V.; Resources, M.H.-R. and L.O.S.-V.; Writing—original draft, M.H.-R. and G.S.V.-A.; Writingreview \& editing, L.O.S.-V. and L.A.G.-C. All authors have read and agreed to the published version of the manuscript.

Funding: This research was funded in part by Fondo de Investigación en Salud, Instituto Mexicano del Seguro Social, México (FIS/IMSS/PROT/PRIO/19/104). Author M.H.-R. has disclosed receipt of financial support for the research, authorship, and/or publication of this article.

Institutional Review Board Statement: Not applicable.

Informed Consent Statement: Not applicable.

Acknowledgments: G.S.V.-A. is a master's student from Programa de Maestría y Doctorado en Ciencias Médicas, Odontológicas y de la Salud, Universidad Nacional Autónoma de México and received fellowship (CVU 928551) from CONACyT through the Padrón Nacional de Posgrados de Calidad.

Conflicts of Interest: The authors declare no conflict of interest.

\section{References}

1. Fauci, A.S.; Lane, H.C. Four Decades of HIV/AIDS Much Accomplished, Much to Do. N. Engl. J. Med. 2020, 383, 1-4. [CrossRef]

2. UNAIDS. Global HIV \& AIDS Statistics 2020 Fact Sheet. Available online: https://www.unaids.org/es/resources/fact-sheet (accessed on 23 March 2021).

3. Iyidogan, P.; Anderson, K.S. Current perspectives on HIV-1 antiretroviral drug resistance. Viruses 2014, 6, 4095-4139. [CrossRef] [PubMed]

4. Gaitán-Cepeda, L.A.; Sánchez-Vargas, O.; Castillo, N. Prevalence of oral candidiasis in HIV/AIDS children in highly active antiretroviral therapy era. A literature analysis. Int. J. STD AIDS 2015, 26, 625-632. [CrossRef]

5. Ceballos-Salobreña, A.; Gaitán-Cepeda, L.A.; Ceballos-Garcia, L.; Lezama-Del Valle, D. Oral lesions in HIV/AIDS patients undergoing highly active antiretroviral treatment including protease inhibitors: A new face of oral AIDS? AIDS Patient Care STDS 2000, 14, 627-635. [CrossRef] [PubMed]

6. Sánchez-Vargas, L.O.; Ortiz-López, N.G.; Villar, M.; Moragues, M.D.; Aguirre, J.M.; Cashat-Cruz, M.; Lopez-Ribot, J.L.; Gaitán-Cepeda, L.A.; Quindós, G. Oral Candida isolates colonizing or infecting human immunodeficiency virus-infected and healthy persons in Mexico. J. Clin. Microbiol. 2005, 43, 4159-4162. [CrossRef] [PubMed]

7. Forsberg, K.; Woodworth, K.; Walters, M.; Berkow, E.L.; Jackson, B.; Chiller, T.; Vallabhaneni, S. Candida auris: The recent emergence of a multidrug-resistant fungal pathogen. Med. Mycol. 2019, 57, 1-12, Erratum in: Med. Mycol. 2019, 57, e7. [CrossRef] [PubMed]

8. Ramírez-Amador, V.; Patton, L.L.; Naglik, J.R.; Nittayananta, W. Innovations for prevention and care of oral candidiasis in HIV-infected individuals: Are they available?-A workshop report. Oral. Dis. 2020, 26 (Suppl. 1), 91-102. [CrossRef] [PubMed]

9. Melo, F.L.; Benati, F.J.; Roman, W.A., Jr.; de Mello, J.C.P.; Nozawa, C.; Linhares, R.E.C. The in vitro antiviral activity of an aliphatic nitro compound from Heteropteris aphrodisiaca. Microbiol. Res. 2008, 163, 136-139. [CrossRef] [PubMed]

10. Nunes, B.C.; Martins, M.M.; Chang, R.; Morais, S.A.; Nascimento, E.A.; de Oliveira, A. Antimicrobial activity, cytotoxicity and selectivity index of Banisteriopsis laevifolia (A. Juss.) B. Gates leaves. Ind. Crops. Prod. 2016, 92, 277-289. [CrossRef]

11. Pádua, M.S.; Mendes-Costa, M.C.; Ferreira, J.M.S.; Magalhães, J.C.; Castro, A.H.F. Assessment of antimicrobial activity in vitro of ethanolic extracts of Banisteriopsis anisandra (A. Juss.) B. Gates (Malpighiaceae). Rev. Bras. Plant Med. 2013, 15, 431-437. [CrossRef]

12. Khan, M.S.; Ahmad, I. Biofilm inhibition by Cymbopogon citratus and Syzygium aromaticum essential oils in the strains of Candida albicans. J. Ethnopharmacol. 2012, 140, 416-423. [CrossRef]

13. Anibal, P.C.; de Cássia Orlandi Sardi, J.; Peixoto, I.T.; de Carvalho Moraes, J.J.; Höfling, J.F. Conventional and alternative antifungal therapies to oral candidiasis. Braz. J. Microbiol. 2010, 41, 824-831. [CrossRef] [PubMed]

14. Sardi, J.C.; Almeida, A.M.; Mendes Giannini, M.J. New antimicrobial therapies used against fungi present in subgingival sites-a brief review. Arch. Oral Biol. 2011, 56, 951-959. [CrossRef]

15. Michelin, D.C.; Sannomiya, M.; Figueiredo, M.E.; Rinaldo, D.; dos Santos, L.C.; Souza-Brito, A.R.M.; Vilegas, W.; Salgado, H.R.N. Antimicrobial activity of Byrsonima species (Malpighiaceae). Rev. Bras. Farmacog. 2008, 18, 690-695. [CrossRef]

16. Anderson, W.R.; Anderson, C.; Davis, C.C. Malpighiaceae. Herbarium, University of Michigan. 2012. Available online: http:/ / herbarium.lsa.umich.edu/malpigh/index.html (accessed on 28 August 2020).

17. Huerta-Reyes, M.; Herrera-Ruiz, M.; González-Cortazar, M.; Zamilpa, A.; León, E.; Reyes-Chilpa, R.; Aguilar-Rojas, A.; Tortoriello, J. Neuropharmacological in vivo effects and phytochemical profile of the extract from the aerial parts of Heteropterys brachiata (L.) DC. (Malpighiaceae). J. Ethnopharmacol. 2013, 146, 311-317. [CrossRef] [PubMed] 
18. Huerta-Reyes, M.; Herrera-Ruiz, M.; Zamilpa-Álvarez, A.; González-Cortazar, M.; Tortoriello-García, J.; Aguilar-Rojas, A. Inventors: Extracto de Heteropterys Brachiata, Método de Obtención y Uso para el Tratamiento de Ansiedad y Depresión. Patent 289104, 29 June 2011.

19. Rex, J.H.; Alexander, B.D.; Andes, D.; Arthington-Skaggs, B.; Brown, S.D.; Chaturvedi, V.; Espinel-Ingroff, A.; Ghannoum, M.A.; Knapp, C.C.; Motyl, M.R.; et al. Reference Method for Broth Dilution Antifungal Susceptibility Testing of Yeasts, Approved Standard3rd ed.; CLSI document M27-A3; Clinical and Laboratory Standards Institute: Wayne, PA, USA, 2008.

20. Bekut, M.; Brkić, S.; Kladar, N.; Dragović, G.; Gavarić, N.; Božin, B. Potential of selected Lamiaceae plants in anti(retro)viral therapy. Pharmacol. Res. 2018, 133, 301-314. [CrossRef]

21. Klos, M.; Van de Venter, M.; Milne, P.J.; Traore, H.N.; Meyer, D.; Oosthuizen, V. In vitro anti-HIV activity of five selected South African medicinal plant extracts. J. Ethnopharmacol. 2009, 124, 182-188. [CrossRef]

22. Laila, U.; Akram, M.; Shariati, M.A.; Hashmi, A.M.; Akhtar, N.; Tahir, I.M. Role of medicinal plants in HIV/AIDS therapy. Clin. Exp. Pharmacol. Physiol. 2019, 46, 1063-1073. [CrossRef] [PubMed]

23. Salehi, B.; Kumar, N.; Şener, B.; Sharifi-Rad, M.; Kılıç, M.; Mahady, G. Medicinal Plants Used in the Treatment of Human Immunodeficiency Virus. Int. J. Mol. Sci. 2018, 19, 1459. [CrossRef]

24. Chaves Valadão, A.L.; Abreu, C.M.; Dias, J.Z.; Arantes, P.; Verli, H.; Tanuri, A.; de Aguiar, R.S. Natural plant alkaloid (Emetine) inhibits HIV-1 replication by interfering with reverse transcriptase activity. Molecules 2015, 20, 11474-11489. [CrossRef]

25. Konoshima, T.; Yasuda, I.; Kashiwada, Y.; Cosentino, L.M.; Lee, K.H. Anti-AIDS agents, 21. Triterpenoid saponins as anti-HIV principles from fruits of Gleditsia japonica and Gymnocladus chinesis, and a structure-activity correlation. J. Nat. Prod. 1995, 58, 1372-1377. [CrossRef]

26. Bessong, P.O.; Obi, C.L.; Andréola, M.L.; Rojas, L.B.; Pouységu, L.; Igumbor, E.; Meyer, J.J.; Quideau, S.; Litvak, S. Evaluation of selected South African medicinal plants for inhibitory properties against human immunodeficiency virus type 1 reverse transcriptase and integrase. J. Ethnopharmacol. 2005, 99, 83-91. [CrossRef]

27. Robinson, W.E., Jr.; Reinecke, M.G.; Abdel Malek, S.; Jia, Q.; Chow, S.A. Inhibitors of HIV-1 replication [corrected; erratum to be published] that inhibit HIV integrase. Proc. Natl. Acad. Aci. USA 1996, 93, 6326-6331. [CrossRef]

28. McDougall, B.; King, P.J.; Wu, B.W.; Hostomsky, Z.; Reinecke, M.G.; Robinson, W.E., Jr. Dicaffeoylquinic and dicaffeoyltartaric acids are selective inhibitors of human immunodeficiency virus type 1 integrase. Antimicrob. Agents Chemother. 1998, 42, 140-146. [CrossRef] [PubMed]

29. Tamayose, C.I.; Torres, P.B.; Roque, N.; Ferreira, M.J.P. HIV-1 reverse transcriptase inhibitory activity of flavones and chlorogenic acid derivatives from Moquiniastrum floribundum (Asteraceae). S. Afr. J. Bot. 2019, 123, 142-146. [CrossRef]

30. Hattori, M.; Ma, C.M.; Wei, Y.; Dine, R.S.E.; Sato, N. Survey of anti-HIV and anti-HCV compounds from Natural sources. Can. Chem. Trans. 2013, 1, 116-140. [CrossRef]

31. Lu, L.; Yu, F.; Cai, L.; Debnath, A.K.; Jiang, S. Development of small-molecule HIV entry inhibitors specifically targeting gp120 or gp41. Curr. Top. Med. Chem. 2016, 16, 1074-1090. [CrossRef]

32. Mehta, A.; Zitzmann, N.; Rudd, P.M.; Block, T.M.; Dwek, R.A. Alphag-glucosidase inhibitors as potential broad based anti-viral agents. FEBS Lett. 1998, 430, 17-22. [CrossRef]

33. Gaitán-Cepeda, L.A.; Martínez-González, M.; Ceballos-Salobreña, A. Oral candidosis as a clinical marker of immune failure in patients with HIV/AIDS on HAART. AIDS Patient Care STDS 2005, 19, 70-77. [CrossRef] [PubMed]

34. Nittayananta, W. Oral fungi in HIV: Challenges in antifungal therapies. Oral Dis. 2016, 22 (Suppl. 1), 107-113. [CrossRef] [PubMed]

35. Gonzalez-Lara, M.F.; Sifuentes-Osornio, J.; Ostrosky-Zeichner, L. Drugs in clinical development for fungal infections. Drugs 2017, 77, 1505-1518. [CrossRef]

36. Soliman, S.; Alnajdy, D.; El-Keblawy, A.A.; Mosa, K.A.; Khoder, G.; Noreddin, A.M. Plants' natural products as alternative promising anti-candida drugs. Pharmacogn. Rev. 2017, 11, 104-122. [CrossRef]

37. Fernández, S.P.; Wasowski, C.; Paladini, A.C.; Marder, M. Synergistic interaction between hesperidin, a natural flavonoid, and diazepam. Eur. J. Pharmacol. 2005, 512, 189-198. [CrossRef]

38. Williams, A.; Friedland, G. Adherence, compliance, and HAART. AIDS Clin. Care 1997, 9, 51-58. [PubMed]

39. Franco, J.B.; Maureira Pena, L.J.; Martins, E.; Martins, F.; Oliveira, M.A.; Ortega, K.L. Regression of human immunodeficiency virus-associated oral Kaposi sarcoma with combined antiretroviral therapy: A case report and literature review. Head Neck 2019, 41, E21-E25. [CrossRef] [PubMed]

40. Mata-Essayag, S.; Magaldi, S.; Hartung de Capriles, C.; Deibis, L.; Verde, G.; Perez, C. "In vitro" antifungal activity of protease inhibitors. Mycopathologia 2001, 152, 135-142. [CrossRef]

41. Chang, E.; Mapakshi, S.R.; Mbang, P.; El-Mallawany, N.K.; Kramer, J.R.; White, D.L.; Chiao, E.Y. Impact of protease inhibitors on HIV-associated Kaposi sarcoma incidence: A systematic review. J. Acquir. Immun. Defic. Syndr. 2018, 79, 141-148. [CrossRef] [PubMed]

42. La Ferla, L.; Pinzone, M.R.; Nunnari, G.; Martellotta, F.; Lleshi, A.; Tirelli, U.; De Paoli, P.; Berretta, M.; Cacopardo, B. Kaposi's sarcoma in HIV-positive patients: The state of art in the HAART-era. Eur. Rev. Med. Pharmacol. Sci. 2013, 17, 2354-2365. [PubMed] 